\title{
SUBSTANTIVE ISLAM \\ (A NEW DIRECTION ON THE IMPLEMENTATION OF ISLAMIC SHARIA ACCORDING TO MUHAMMAD SAID AL- ASHMAWI)
}

\author{
Aksin Wijaya \\ State Islamic Collage (IAIN) Ponorogo \\ asawijaya@yahoo.com
}

\begin{abstract}
It is undeniable that the emergence of movement for applying Sharia in people's life and its implementation is considered as an evidence of islamic authenticity. Therefore, they occasionally enforce people to apply it. Someone who does not support this movement is regarded as untruthful Muslims and even accused of being infidels that must be eradicated from the earth. On the contrary, Muhammad Said al-Ashmawi proposes that the application of religious dimensions as an ideal substance of Islam should respect the humanitarian aspects due to the essential concept that Islam is one, and the Shari'ah is diverse. Thus, the application of Islam should take the diversity of the sharia into account.
\end{abstract}

Keywords: Substantive Islam, one Islam, the diversity of sharia, merciful sharia

\section{Introduction}

Islam, in theology, is one but it has various epistemology (Wijaya, 2014). The diversity of Islamic epistemology leads to the diversity of Islamic thoughts since every thought is actually derived from epistemology and the thinkers' response to either realities of the fact and thought developed in their time. Several schools of thought such as idealistic, transformative and reformative schools of thoughts emerged then in the Middle East (Boullota, 2002, p. 4); (Saukani, 1994, p. 25). Their main concern was the relationship of tradition and modernity, and the implementation of Islamic sharia. They began to discuss again the two themes after the defeat of the Arab world against Israel in the 1960.

One Islamic thinker involved into the struggle around this was Muhammad Said al-Ashmawi who proposed Substantive Islam. Ashmawi's papers used to be preceded by his anxiety to the phenomenon of the emergence of the movement of thought about to implement sharia law in countries with predominantly Muslims, especially Egypt. They stated that Islamic countries suffered a setback as they took and adopted Western civilization. To gain progress in Islamic countries, the true Muslims should hold the tradition of Islam by taking the example of the Islamic revolution in Iran. The question arouse in Ashmawi's mind: is the model of Iran called as Islam and the application of sharia law? What is exactly the nature of sharia and how to apply it? (al-Ashmawi, 1993., p. 15)

According to Ashmawi, efforts to implement Islamic sharia is a good thing, but it must be based on the right understanding on the essence of Islam, Islamic sharia, Islamic jurisprudence following the model and its application. A correct understanding is based on a scientific approach ((Al-Ashmawi, 1993, p. 16), by using reason as the device. Ashmawi thought that ((Al-Ashmawi, 1993, pp. 28-29) one's understanding (Descartes, 2000, p. 24) is different from another since they are affiliated to the state, circumstances, and different thinking systems (al-Shabistari., 2013). This affiliation affects their views in understanding things, including religion. Further, 
Ashmawi requires proper understand on the Qur'an, especially in two things which are the language of the Qur'an and the reality in which the Qur'an revealed and was about to use, since every language, so as the reality, develops (al-Ashmawi M. S., 2004, pp. 7996). Someone who is not keen on seeing the development of both would put overlapping understanding of the Qur'an.

Based on the above background, the focus of this article is Ashmawi's imani (substantive) reasoning of Islam which is the basis of reviewing various other Islamic discourses. Later, three points will be discussed: first, how is Ashmawi's method of thought? Second, how is Ashmawi's Islamic substantive reasoning? Third, how is the concept of Sharia application according to Ashmawi?

This article aims to reveal Ashmawi's arguments in Islamic substantive reasoning by using descriptive method, figure study approach. The study of figure thought has got two objectives: first, to understand the thought objectively and descriptively; second, to track and uncover arguments and unspeakable interests behind the thought, for example, why the figure states a certain idea. Both objectives utilize different method, approach and theory. The first objective may use method of descriptive thinking, while the second employs critical method. Both studies can use the hermeneutic approach, yet in a different theory of hermeneutic. (Wijaya, 2014:6-14). As mentioned above, this study aims at describing the figure (Ashmawi's) thought objectively-descriptively. So, I will use theoretical hermeneutic (objective).

In its application, theoretical hermeneutics employs two other approach devices: psychology reviewing the biography, and linguistic reviewing the works. I will examined the biography of the figure first, followed by the reading his work. With this logic, I will recognize the figure's intention within his work. This theory helps determine objectively Ashmawi's Islamic reasoning method. What will be found in this article is an objective description of three parts contained in Ashmawi's religious reasoning methods: root, contents, and results. Moreover, nearly all Ashmawi's works are collections of articles that there are repetitions of discussion in them.

A few scholar of research on Ashmawi were: Saqiv compared between Ashmawi with other scholars in Egypt (Saqiv, 1992); Shepard wrote about application of the sharia according to Ashmawi in Egypt (Shepard, 1996); Fluehr wrote about politics according to Ashmawi (Fluehr-Lobban, 1998) and Nasir wrote about hijab according to Ashmawi (Nasir, 2004). This article will continu ther's research, and focus on Ashmawi's imani (substantive) reasoning of Islam and application of new sharia.

\section{Intellectual Biography of Muhammad Said al-Ashmawi}

Muhammad Said al-Ashmawi, a critical Muslim intellectual, was born in 1932 in Egypt. This graduate of the faculty of Law, Cairo University in 1954, once had been a prosecutor assistant in the province of Alexandria. After a long period of time, his career began to rise into the provincial prosecutor of Alexandria in 1959. In about 1960, al-Ashmawi occupied a new position of a judge, prosecutor and then a chairman in 1971. In 1974, his career climbed again to the chief of prosecutor in the province of Central Cairo. In 1977, he was promoted to be advisor the State, especially in law making. It seems that his career is not everything for him that in 1978 he pursued his studies at Harvard Law School in the United States. Once completing his study in the United States, al-Ashmawi was given responsibility as a judge Court of Egypt, and further he was promoted to chairman. In 1981, he was also a chairman of the Criminal Court and the chairman of the State Security Court, a special court handling cases of treason and resistance of certain groups against the State (Sagiv, 1995: 71); (Nasir, 2004) 
In 1970, al-Ashmawi strongly opposed the President's effort intended to accept the Islamic Constitution proposal posed by a particular group of Islamic movements in Egypt who wished to make Egypt an Islamic State. al-Asmawi claimed that this would result in dichotomy and marginalization of Muslims and other communities, especially non-Muslims such as the Christians and the Coptic minority. According to Ashmawi, individual relationship with the state is not a religious relationship (Carolyn, 2002: 22). This movement turned out to be a very powerful one. When they failed to submit a proposal, they did the jihadist movement. In 1981, Ashmawi also adjudicated some Jemaah Jihad movements and the Nasiris who destabilized Egypt as a democratic country. Jemaah Jihad is one Islamic movement that sought to overthrow the legitimate government and rejected the democratic system. It was a member of Jemaah Jihad who assassinated President Anwar Sadat on October 3, 1981 when the president was observing the military parade commemorating the 1973 war.

After the death of President Sadat, the hardline Islamic movement launched endless, even more rampant, efforts, especially in the era of Hosni Mubarak who continued the leadership of Anwar Sadat. They targeted figures and intellectuals considered to impede their movement. Their action was culminated in the assassination of Faraj Foda, a columnist critic of Islamic fundamentalism, in July 1992. Besides, they also threatened al-Ashmawi especially after the publication of Usul al-Shariah, which was also the target of the Shaykh al-Azhar to block it from the exhibition book of Cairo International book. Since Ashmawi still served as the chairman of the Egypt court, President Hosni Mubarak to intervened and the blocking was canceled.

In addition to being a government official, Muhammad Said al-Ashmawi was also widely known as an intellectual who hadan expertise in the field of Islamic law (Sharia), Usuluddin, comparative religion and comparative law. His intellectual pace was proven through talks and lectures at various seminars and universities, both inside the country and overseas. This contemporary Muslim intellectual who proposed fresh and critical ideas wrote several works:1) Risalah al-Wujud (AlAshmawi); 2) Tarikh al-Wujudiyah al-Fikr al-Bashari, (Al-Ashmawi,1963); 3) Conscience of the Age, (Al-Ashmawi, 1968); 4) Jawhar al-Islam, (Al-Ashmawi, 1984); 5) Rub al-Adalah, (Al-Ashmawi, 1986); 6) Al-Riba wa al-Fa'idah fi al-Islam, (AlAshmawi, 1988); 7) Al-Shariah al-Islamiyah wa al-Qanun al-Misri, (Al-Ashmawi, 1988); 8) Haqiqatu al-Hijab wa al-Hujjiyatu al-Hadith (Al-Ashmawi); 9) al-Islam al-Siyasi (Al-Ashmawi, 2004); 10) al-Usul al-Misriyah li al-Yahudiyah (Al-Ashmawi, 2004); 11) Hasad al-Aqli (Al-Ashmawi, 2004);12) Ma'alim al-Islam (Al-Ashmawi, 2004); 13) alKhilafah al-Islamiyah (Al-Ashmawi, 2004); and14) Usul al-Shari'ah (Al-Ashmawi, 2013).

\section{Ashmawi's Reasoning Method}

Ashmawi departed on two elements in the Islamic reasoning. First, the scientific method (Al-Ashmawi, 2004; 16). Thinking does not derive from an empty space. Thinking always includes the frame of civilization and logic. According to Descartes, the quality of human mind is the same for everyone; no one is superior compared to other persons.The way humans use their intelligences and the objects concerning each intellect distinguishes one into another (Soros, 2009; 30). Hence, owning good intellect is not enough, since the most important thing is on how well it is used. Culture and civilization affiliated to each person affect the use of intellect. Abid al-Jabiri called this as formed reasoning (al-'aql al-mukawwan), that is "a collection of rules and laws of thinking given by a particular culture to its adherents as a foundation for acquiring knowledge" (Al-Jabiri, 1991; 15). Therefore, a side formed by the rules 
and laws of thinking, thinking is also shaped by civilization. Arab reasoning is formed by Arab civilization, and Western thinking is also shaped by Western civilization.

As a human product, civilization undergoes changes. Ashmawi divided the civilization shift into three period categories: ideological, technological and humanistic. Ideological period is different from technological period. In the ideological period, the world is still fragmented, whereas in technological period humans starts becoming one since they can live in harmony in one place called global Village. In ideological period, people hold on physical things and division of labor, while in technological period they adhere to the intellect, will and the human competition. In addition, in the ideological period the society is closed, because they only live in one community embracing the same ideology, whereas in technological period the society is open to anyone without barrier of ideology. In the ideological period, one value was only for one community, while at the technologic period, the value is for human society as a whole. Human period appeared in between these periods ('ashr al-insan) (Al-Ashmawi, 2004; 25-40).

Community unity in this technological period then resulted in the unity or one unified thought between the West and Islam, even though the West was given more value. The West became a universal civilization. The Western thought was the same as the idea of humanity (Al-Ashmawi, 2004; 19-20), yet the West meant by Ashmawi was the West in the technological period. Ashmawi lead us to think more in the realm of technology since he was not obstructed by a particular ideology. Technological reasoning invited us to think open. Even though the technology was still in the grip of certain ideologies, such as the capitalist, Ashmawi invited to release it from the influence of ideology, while making it as a thinking tool. Technologic law was different from static and closed law of ideology. Through technology, people were not only made to be one but also to be open and move fast.

Second, is the reasoning method of al-Qur'an. Ashmawi proposed an idea of the alive Qur'an. He said alive, bicouse of: first, al-Quran was not revealed all at once as other holy books such as Torah which was revealed one time to Prophet Moses. AlQur'an was revealed gradually. Second, al-Qur'an revealed in Mecca and Medina. AlQur'an makkiyah only discusses the issues on religion since Muslims had not existed yet. Al-Qur'an still invited people to believe in Allah only, refuse to worship statues, and to explain Allah's grace and torment. After Muslims' movement to Medina, Muslim society was built and then sharia was established either to explain the law of mu'amalah or hudud sharia. Third, al-Qur'an came in the form of dialogues of two sides, question and answer such as in (al-Baqarah:219, 189; al-Isra':58, and al-Nisa':176). The style of the dialogue involves laws and faith. Fourth, al-Qur'an revealed by asbab nuzul which in contemporary term is called historical dimension of al-Qur'an. Fifth, with asbab nuzul, elimination events (nasikh-mansukh) of al-Qur'an verses which proved the life and living evidence and the dynamic al-Qur'an. (Al-Ashmawi, 2004; 79-86).

Besides being alive, Ashmawi contends that al-Qur'an is a concise and absolute divine revelation. Therefore, al-Qur'an came in abundant words. Its arrangement includes words with diverse roots, far distinctive meaning and various purposes. Words derived from non-Arab which then adopted into Arabic and Arabized can be found in al-Qur'an. Mixing words is a necessity since language is part of the civilization history. Civilization shifts causes changes in the language, not to mention the word contained in al-Qur'an (Al-Ashmawi, 2013; 45). Thus, it is inevitable that different arguments occur among Muslims in understanding the lafaz written in al-Qur'an, particularly those related to hija 'iyah letters, lafaz-lafaz and sentences (Al-Ashmawi, 2004; 85-89).

Hadith is also an important source of Islamic teaching after al-Qur'an. When 
the Prophet lived, his Companions were not allowed to write hadith. After the Prophet's death, some companions had different opinions on the collection of of hadith. After a long debate, the Islamic scholars recorded hadith in various forms. The first is saheh hadith of which the compilation is based on themes, for example about prayers. There are two kinds of this hadith called Bukhari and Muslim. The second form is called Musnad, which is based on sanad or hadith narrators like musnad of Ahmad bin Hambal. The third is Sunan hadith which is collected based on law themes such as Sunan Abu Daud dan Tirmidzi (Al-Ashmawi, 2004; 81-84).

Hadith had just been collected in the second half of the second Hijriyah, the second period of the early third centuryor approximately two centuries after the Prophet's death. This long period of time obscures the collection of hadith resulted in the emergence of hadith mawdu'. The Islamic scholars made rules for hadith saheh and hadith mawdu'. In this case, both conceptual and practical prudence and critical attitude towards hadith are necessary.

The concept of hadith term means good news. Meanwhile, hadith also means good news related to the Prophet's deeds, words, and recognition. In the study of hadith, two dimensions of hadith which sanad and matan emerge. The characteristics of hadith are also divided into three: hadith mutawatir, hadith mashhur and hadith ahad. Hadith ahad has zanni character. Thus, practically,the hadith and jurisprudence experts especially refuse the use of hadith ahad like as Shi' ite, Mu'tazilites and some Khawarij people. The majority of scholars believe that hadith ahad cannot be used only for aqidah issues, either those related to religion or sharia.Yet, it can be used for amaliyah matters. Therefore, ones should not hold hadith ahad, nevertheless, those who believe in it should never be called as infidels.

\section{Substantive Islam Reasoning According to Ashmawi}

In the two principles of thought, Ashmawi's thought reflecting his Substantive Islam reasoning will be discussed. The term Substantive Islam is taken from Ashmawi's work entitled Jawhar al-Islam (1993). This book talks about the dichotomy of religion and religious thought, the unity of religion and tatbiq al-Shari'a.

\section{Religion and Religious Thought}

In understanding religion, Ashmawi departs from the authority between God and Prophet Muhammad. These two subjects are in different positions. God is as an active part, whereas Muhammad takes a passive position. God is as the one who determines the sharia (Shari'), who speaks (Qa'il), and who command (Amir), while Muhammad is as the one who is given sharia (mashru'), who is commanded (ma'mur) and who is the target of the saying $(m a q u l)$. Therefore, Muhammad basically does not have any authority (Al-Ashmawi, 2004: 55-58). Yet, Muhammad's position sometimes has became a second Shari', second Qa'il, and second Amir, and being a subject to be obeyed after receiving mandate from God, hence obeying Muhammad is the same as obeying God (Tharabasyi, 2010: 9-85; Syahrur, 2012: 83-115). Therefore, beside al-Qur'an as divine words, hadith as the Prophet words is also one of religion sources.

In this logic, religion according to Ashmawi is everything derives from the Prophet either which is stated in al-Qur'an or hadith in either hadith fi'liyah, qawliyah or taqririyah. In this level, revelation is considered as alive. However, after the Prophet's death, al-Qur'an can neither speak nor explaining itself. The alive revelation changes epistemologically into died revelation, especially once it becomes Mushaf (manuscript) (Abu Zaid, 2010: 197-217), which Arkoun called as Closed Official Corpus (Arkoun, 2001). Thus, according to Ashmawi, al-Qur'an needs sharah, interpretation, and 
ijtihad from some Muslims. The result of this Muslim's creation is called religious thought. It is not a religion, yet it is something that moves around religion. It cannot occupy the position of religion. It be right or also wrong (Al-Najjar, 1995). It is relative and bound to time and space.

In case religion is a set of principles brought by prophets and apostles as the mandatory of God, religious thought is the historical dimension of human understanding of religion and its implementation. Hence, the thought could suit or also distinctive from religion. According to Ashmawi, such distinction could not be understood obviously before the people, including among Prophet's Companions like the case of alms payment (At-Taubah: 103) occurred after the Prophet's death between Abu Bakr and Umar bin Khattab (Al-Ashmawi, 2004: 96-100).

\section{One Islam, Varied Sharia}

Distinguishing religion to the religious discourse is important when we interpret the concept of al-Qur'an on Islam. For so far, when we hear the word "Islam" said, our mind refers to the religion brought by the Prophet Muhammad. Or, if we hear the name of Prophet Muhammad, we directly refer to the religion named "Islam". Islam which was revealed to the Prophet Muhammad is believed to be not only a perfect religion (Ali Imran: 85) but also a religion blessed by Allah. Therefore, someone's religion is not accepted by Allah except Islam (Al-Maidah: 3).

Such common belief among Muslims worth thinking considering al- Qur'an views Islam as a single thing since it derives from the Oneness (al-Mukminun: 52). The oneness of Islam is supported by the normative data that prophets before the Prophet Muhammad were called "Muslims" by al-Qur'an (Shahrur, 1996: 31-33; Al-Ashmawi, 1993: 118-119). They shared the same religion as the Prophet Muhammad, which is Islam (the core teaching of monotheism). Even though the Qur'an mentions the religion of the prophets was one, the sharia revealed to them varied (Shura: 13, 21; alJasiyah:18).

\section{Islam: to Believe and to Persist}

What is Islam? According Ashmawi, Islam is a relationship between creature and creator (Khaliq) (Ali Imran: 83; al-Baqarah: 112). The relationship takes the form of faith, and stay continuously in the faith (Fussilat: 6, 30; al-Ahqaf: 13) (Al-Ashmawi, 1993: 128-131). In detail, according to al-Qur'an, Islam cored three fundamental pillars: first, recite the first shahadah from the two kalimat shahadah, "I bear witness that there no God but Allah"; second, believe in the doomsday; and third, do good deeds (al-Baqarah: 62). Therefore, it can be understood that Islam is admission of the existence of Allah and the doomsday. If the admission is combined with good deeds, the doer is called a Muslim (al-Baqarah: 112, 128; al-Ambiya:108, Yunus:90; al-Nisa':125 and al-Maidah:44). Since all Heavenly religion believe in the three elements, that those religions are called Islam (Shahrur: 18; Al-Thabari, 2004: 393-399). This means that Islam is the core teaching of prophets.

The addition of the "second syahadat" that is witnessing that the Prophet Muhammad is the messenger of Allah referring to the figure of the Prophet paired to the "the first shahadah" distinguishes those Heavenly religions (Al-Ashmawi, 1993: 120-123). The Islamic religion which made Abrahamits prophet is called Hanafiyah Islam, the Islamic religion which made Mosesits prophet is called Jews (yahudiyah) Islam, the Islamic religion which made Jesusits prophet is called Christian (nasraniyah) Islam, whereas the Islamic religion which made Muhammadits prophet is called Imani Islam. In line to this principle, a hanafiyah, yahudiyah or nasraniyah Muslim can be a Mukmin if they believe in Allah, doomsday and good deeds which are the requirement of becoming a Muslim (Islamic Principles), and believe in 
Muhammad as their Prophet (second syahadat). By reciting two Shahadah saying "I bear witness that there is no God but Allah, and I bear witness that the Prophet Muhammad is the messenger of Allah", then someone can be called as imani Muslim.

Thus, Ashmawi distinguishes Islam from Iman (Al-Ashmawi, 1993: 128-130) since al-Quran refuses the claim of Baduwi Arab people who admit themselves as believers but al-Qur'an urges Muhammad to ask them to say we have believed in Islam because iman has not come into their heart (al-Hujarat:14; al-Ahzab:35). In line with this distinction, al-Qur'an distinguishes Muslims from Mukmins. People who followed the true religion since Noah to Prophet Muhammad are called the Muslims, whereas people in particular who follow the Prophet Muhammad are called Mukmins (AlAshmawi, 1993: 127-128) for al-Qur'an addresses people of the Prophet Muhammad by saying "ya ayyuhalladzina amanu" (Hi people who believe), not addressing "ya ayyuhalladzi aslamu" (Hi people who adhere to Islam) (al-Nisa':162; al-Taubah:122; AnNur: 62; al-Hujarat: 15; ali-Imran:121; al-Annaml: 1, 64; al-Baqarah: 104, 183).

\section{New Model of Sharia Implementation}

At this point, Ashmawi's view on the sharia implementation which has been a controversy theme in many countries inhabited by the majority of Muslims will be presented here. What are actually implemented from Islam?

\section{Islam: Religion and Sharia}

Ashmawi departs from the dichotomy of makkiyah al-Qur'an and madaniyah al-Qur'an to distinguish Islam as a religion and Islam as a sharia. This thought comes from an assumption that Islam is inseparable from the prophetic history of Muhammad (Darwazah, $1400 \mathrm{H}:$ 374-375). Based on the prophetic history of Muhammad, Islam develops in two sacred places for Muslims, the places where the Prophet Muhammad preached: Mecca and Medina. The basic distinctions between Islam in al-Qur'an makkiyah and al-Qur'an madaniyah are different situation and condition (Darwazah, $1400 \mathrm{H}:$ 372-373). Al-Qur'an in Mecca was revealed in the preaching period (Darwazah, 1951: 12), on the other hand, Muslims were in the weak position. In this circumstance, Sharia had not been needed yet to regulate them. What was needed was the basic principles of common sharia, particularly in the issues of faith and some worships such as verses on prayers and alms which were revealed in Mecca and advice on patience. And Sharia regulation was necessary to arrange the system of government in Medina, especially in the field of attitude, social, politics, economy, and family. These two elements of Islamic sharia are interrelated. Syari'at qur'ani revealed in Mecca has principal and theoretical characters, whereas syari'at qur'ani revealed in Medina was as technical and practical development from syari'at qur'ani of Mecca. Principal sharia was applied in the form of preaching suited the condition of Mecca, while the other sharia appropriate the condition of Medina (Al-Ashmawi, 2004: 85-86).

The term "sharia" has existed before the coming of al-Qur'an. It has been used within the Torah, Talmud and Bible (Al-Ashmawi, 2013: 46-55). There are only four verses mentioning the term sharia in al-Qur'an in three categories: the three are included in al-Qur'an makkiyah (al-Jatsiyah:18; al-Syura:13; al-Syura: 21), and the last one verse is part of al-Qur'an madaniyah (Al-Ashmawi, 2013: 56-58). Meanwhile, within Islamic tradition, the term sharia undergoes meaning development: first, sharia means Islamic method; second, it means every religious law, that is anything comes from al-Qur'an such as religious methods, rules in worships, punishments and mu'amalah (transaction); third, every religious law comes from al-Qur'an, rules in worship, punishment, and mu'amalah, and also everything stated in the hadith, Jurists arguments, interpretations of the interpreters and explanation from the scholars. Thus, the term sharia as been 
used not in its original meaning anymore, but it has undergoes various understanding, especially in the understanding of Islamic Jurists. (Al-Ashmawi, 2013: 58-64)

\section{The Implementation of Dynamic-Merciful Sharia}

Ashmawi distinguish between: first, general aqidah (faith). It sees that Islam as a religious system, not a political system. As a religious system, aqidah has an open character before human within any space and time; second, a dynamic sharia. It means that Islam is a way of life which moves together with the movement of reality and its law changes as the reality alteration moves. It moves forward through intellectual's creative diligence (ijtihad). The thought on nasikh and mansukh (abrogate and abrogated) in al-Qur'an, according to Ashmawi, has been a normative evidence on how al-Qur'an as a basic source of Islam undergoes a shift movement together with the reality. The law of al-Qur'an does not come from outside of the reality and yet it is not revealed all at once. It is revealed from within the reality and gradually, verse by verse and surah by surah in approximately 23 years. Ashmawi take an example of how the verse on inheritance was revealed gradually (Al-Ashmawi : 71-78).

Since the term sharia echoed by some Muslims over the years means a religious thought, Ashmawi distinguishes further between divine sharia as a religion and sharia thought as a result of human thought. The divine sharia is absolut, whereas sharia law is relative since it is human creation bound by space and time. Divine sharia is as a dynamic method, while human sharia is a restricted product and validity period. Departed from the distinction, according to Ashmawi, divine sharia is based on two elements: method and principle. In term of method sharia is dynamic, while in its principle it put iman (faith) before practice. Meanwhile, human creation is law of sharia. According to Ashmawi, the law of sharia is divided into two: the divine (tawqifi), and ijtihadi part (Al-Ashmawi, 2004: 35), either those related to ahwal shakhshiyah or mu'amalah or jinayah. Jinayah is divided again into three elements: hudud, qisas and ta'zir (Al-Ashmawi, 2004: 50-53).

In practice, according to Ashmawi, divine law only occurred during Prophet Muhammad's life. After the death of this Muslim's great prophet, madani law or human-made law was applicable (Al-Ashmawi, 2004: 69). Divine law could have straight forward or intermediary character (Al-Ashmawi, 2004: 70). The example of straight forward character is the punishment given to the people in the past, whereas the intermediary characteris through the prophets. The prophet represents God. When the prophets make mistakes as a human being, Allah rebuke dimmediately. For instance, the Prophet was warned by God when he turned away with a surly from Ibnu Ummi Maktum which then surah abasa was revealed (Salim, 2008: 251-256). Will God rebuke the scholars today when they make a mistake? The answer is definitely, no. This proves that the law applicable after the Prophet Muhammad's death was human relative and profane law.

Ashmawi contends that Islam brought by Prophet Muhammad is called imani Islam of merciful sharia. There are many verses in al-Qur'an showing the teaching of grace, like in the expression of basmalah "bismillahi al-Rahmani al-Rahim", The Merciful and Beneficent God. Rahman has general meaning covering all human, Rahim has specific meaning only for people who practice the sharia. The Prophet Muhammad said: "I am a prophet of mercy". This distinction is important that the implementation of Islamic sharia brings mercy to human (Salim, 2008: 21) instead of bringing misery and divisions for mankind. Even in implementing a hard punishment like qisas, al-Qur'an suggests that mercy be practiced (al-Baqarah:178) (Al-Ashmawi, 2004: 20-21).

Ashmawi claims that Islamic movement groups which over years have strictly 
voiced the implementation of Islamic sharia do not practice the merciful Islamic sharia taught by imani Islam, but they implement sharia law created by the jurists in their time. Hence, according to Ashmawi, divine sharia needs to be distinguished from human (bashari) sharia that causes different implementation and result. Since divine sharia is mercy sharia, thus its practice must depart from the proper principle that is putting stabilization of faith before the implementation. Someone would not commit adultery if he is still a believer.The belief is the substance teaching of Islam according to Ashmawi (Al-Ashmawi, 2004: 26). If we make faith as the substance dimension of Imani Islam brought by Prophet Muhammad, then its implementation should be mercy.

In the context of ahwal al-shakhsiyah, such as the issues on marriage, alms, inheritance, and mu'amalah (transaction), both teachings of divine sharia and law sharia can be found in them. In the divine sharia, even though there is a charge to implement the execution of commands and prohibitions, the lightest always be recommended in practice. Likewise in jinayah (crime), there are three models of jinayah: hudud, qisas dan ta'zir; from which divine sharia tolerates mu'asharah bi al-ma'ruf (being friends with goodness) and rahmah (mercy) by not leaving the enforcement of justice. Since the human creation sharia is applicable after the Prophet's death, then the implementation would not use the first two jinayah, hudud and qisas. What is truly used these days is ta'zir.

\section{Conclusion}

To sum up, Ashmawi considers Islam as one, but Islamic Sharia is diverse. Furthermore, Ashmawi proposed a new model of Islamic Sharia implementation thought that is iman-ilahi (faith-divine) Sharia, not fiqh-bashari (human jurisprudence) sharia echoed by some Islamic movements over the years.

\section{Reference}

Abu Zayd, Nasr Hamid. 2010. al-Tajdid wa al-Tahrim wa al-Ta'wil: bayna al-Ma'rifah al-'Ilmiyah wa al-Khawf min al-Takfir, Maroko: Dar al-Bayda'-Markaz Th aqafi al-'Arabi.

Arkoun, Muhammad. 2001. Islam Kontemporer, transl. Ruslani, Yogyakarta: Pustaka Pelajar.

al-Ashmawi, Muhammad Said. 1993. Jawhar al-Islam, Kairo: Sina li al-Nashr. . 2004. al-Islam al-Siyasi, $5^{\text {th }}$ edition, Libanon-Beyrut: al-Intishar al'Arab. .2004. al-Usul al-Misriyah li al-Yahudiyah, Libanon-Beyrut: al-Intishar al-'Arabi.

2004. Hasad al-Aqli, $3^{\text {rd }}$ edition, Beyrut: al-Intishar al-'Arabi

2004. Ma'alim al-Islam, $2^{\text {nd }}$ edition, Beyrut: al-Intishar al-'Arabi. . 2004. al-Khilafah al-Islamiyah, $5^{\text {th }}$ edition, Libanon-Beyrut: al-Intishar al-'Arabi.

2013. Usul al-Shari'ah, $6^{\text {th }}$ edition, Kairo: Dar al-Thunani li al-Nashr.

Boullota, Issa J. 2002. Dekonstruksi Tradisi, Gelegar Pemikiran Arab Islam, transl. Imam Khoiri, Yogyakarta: LKiS.

Darwazah, Muhammad Izzat. N.y. al-Dustur al-Qur'ani fi Shu'un al-Hayah, Dar alIhya' al-Kutub al-'Arabiyyah.

1951. al-Qur'an wa al-Daman al-Ijtima'i, Beyrut: Maktabah al-'Asriyah

. 1400 H Sirah Rasul: Suwarun Muqtabisatun min al-Qur'an al-Karim, two 
volumes, Beyrut: al-Maktabah al-'Asriyyah

Descartes, Rene. 2000. Maqal an Minhaj al-'Ilmi, translated to Arabic, Mahmud alKhadiri, Kairo: al-Hay'ah al-Misriyyah al-Amah li al-Kitab.

Esack, Farid. 2000. al-Qur'an, Liberalisme, Pluralisme: Membebaskan Yang Tertindas, terj.Watung A. Budiman, Bandung: Mizan.

Al-Jabiri, Muhammad 'Abid. 1991. Takwin Aql al-' Arabi, Beyrut: Markazu al-Thaqafi al-'Arabi.

Kuntowijoyo. 2003. Metodologi Sejarah, $2^{\text {nd }}$ edition, Yogyakarta: Tiara Wacana

Fluehr-Lobban, Carolyn (ed), 1998. Against Islamic Extremism: The Writings of Muhammad Said al-Ashmawi. Florida, University of Florida Press.

Rahman, Fazlur. 1997. Neomodernisme Islam, transl. Taufiq Adnan Amal. Bandung: Mizan.

Sagiv, David. 1995. Fundamentalism and intellectuals in Fgipt 1971-1993. London: Frank Cass. , 1992. "Judge Ashmawi and Militant Islam in Egypt". In Middle Eastern Studies, Vol. 28, No. 3, July.

Saukani, Lutfi. 1998. "Islam dalam Konteks Pemikiran Pasca-Moderne: Pendekatan Menuju Kritik Akal Islam", in Journal of Ulumul Qur'an, nomor 1, vol. V 1994; Journal of Paramadina.

al-Shabistari, Shekh Mujtahid. 2013. Hermeneutiqa al-Qur'an wa al-Sunnah. Beyrut: alIntishar al-'Arabi.

Shepard, William E. 1996. "Muhammad Sa'id al-Ashmawi and the Application of Sharia in Egypt", in International Journal for Middle Eastern Studies, no.28,

Soros, Abdul Karim. 2009. al-'Aqlu wa al-Hurriyatu, transl. Ahmad al-Qobanji. Beirut, Libanon: Manshurat al-Jamal.

Syahrur, Muhammad. 2012. al-Sunnah al-Rasulilyah wa al-Sunnah al-Nabawiyah:Ru'yah Jadidah. Libanon-Beyrut: Dar al-Saqi.

Tarabasyi, Jurij. 2010. min Islam al-Qur'an ila Islam Hadith: al-Nash'ah alMusta'nafah, eds. $2^{\text {nd }}$. Libanon- Beirut: Dar al-Saqi

Al-Thabari. 2004. Tafsir al-Tabari al-Musamma Jami'a al-Bayan fi Ta'wil al-Qur'an, Kairo: Maktabah al-Tawfiqiyah.

Umr al-Najjar, Abdul Majid. 1995. Fiqhu al-Tadayyun: Fahman wa Tanzilan, alZaytuniyyah li Nashr wa al-Tawzi'.

Wijaya, Aksin. 2014. Satu Islam, Ragam Epistemologi. Yogyakarta: Pustaka Pelajar . 2014. Nalar Kritis Epistemologi Islam. Yogyakarta: Teras. 